\title{
Vicia sativa Roth. Can Reduce Soil and Water Losses in Recently Planted Vineyards (Vitis vinifera L.)
}

\author{
Jesús Rodrigo-Comino ${ }^{1,2} \oplus \cdot$ Enric Terol $^{3} \cdot$ Gaspar Mora $^{3} \cdot$ Antonio Giménez-Morera $^{4} \cdot$ Artemi Cerdà $^{1}$
}

Received: 2 October 2020 / Accepted: 16 November 2020 / Published online: 2 December 2020

(c) The Author(s) 2020

\begin{abstract}
Elevated soil loss and runoff rates can reduce soil fertility; therefore, soil erosion control strategies must be implemented at the hillslope and watershed scale when plantations are established and the soil is bare. In this research, we propose the use of the Vicia sativa Roth. to reduce the soil losses during the first year to control the peak of soil erosion after the plantation in tilled vineyards. To test its efficiency, rainfall simulation experiments were carried out with field surveys in The Casa Pago Gran, in the Eastern Iberian Peninsula. Our results demonstrate that soil properties (organic matter and soil bulk density) and soil erosion (soil loss, runoff and sediment concentration) were significantly different between the control plot (tilled) and with cover crops along with August 2016, 2017 and 2018 measurement periods, but not during January 2016, coinciding with the initial survey before the vetch sown. Runoff initiation was delayed in 3.7 times after 3 years (from 190 till $709 \mathrm{~s}$ ). The runoff discharge was reduced by the Vicia sativa from 32.87 till $13.68 \%$, the sediment concentration went down from 18.54 till $3.81 \mathrm{gr} \mathrm{l}^{-1}$ and the soil erosion from 3.36 to $0.29 \mathrm{Mg} \mathrm{ha}^{-1} \mathrm{year}^{-1}$. An increase in soil bulk density was registered but did not affect the runoff generation either the soil losses, that was reduced by the plant cover. We conclude that it is necessary to include soil erosion control measures such as the use of Vicia sativa to reduce soil erosion processes during the first stages of the vineyard plantations due to the soil quality improvements and the reduction in soil and water losses.
\end{abstract}

Keywords Soil erosion $\cdot$ Vineyards $\cdot$ Soil management system $\cdot$ Land degradation

Jesús Rodrigo-Comino

jesus.rodrigo@uv.es

Enric Terol

eterol@cgf.upv.es

Gaspar Mora

joamona@cgf.upv.es

Antonio Giménez-Morera

angimo1@doctor.upv.es

Artemi Cerdà

artemio.cerda@uv.es

1 Soil Erosion and Degradation Research Group, Department of Geography, Valencia University, Blasco Ibàñez, 28, 46010 Valencia, Spain

2 Department of Physical Geography, University of Trier, 54296 Trier, Germany

3 Department of Cartographic Engineering, Geodesy, and Photogrammetry, Universitat Politècnica de València, Camino de Vera, s/n, 46022 Valencia, Spain

4 Departamento de Economía y Ciencias Sociales, Escuela Politécnica Superior de Alcoy, Universitat Politècnica de València. Plaza Ferrandiz y Carbonell s/n, Alcoy, 03801 Alicante, Spain

\section{Introduction}

Soil erosion has been found not sustainable in many agriculture landscapes of the world (e.g.,Bayramin et al. 2006; Mohammed et al. 2020b; Panagos and Katsoyiannis 2019) inducing severe land degradation processes (García-Ruiz et al. 2015; Salvati et al. 2016). The strategies to control soil erosion were terracing and afforestation (Smith 1914) but until the 1930s the experimental and restoration approaches were few and based on engineering strategies such as improve the drainage or terracing, and plants were not seen as a proper option. The use of experimental research in the 1930s in the USA resulted in a better understanding of the soil erosion processes (Lutz 1935) and the initiation of the soil erosion control research (Ayres 1937) based on the understanding of soil erosion process and related mechanism (Ellison 1945). This was also the time that the soil erosion research was spread to different parts of the world (Stamp 1938) and, then, plants were found to be a suitable option to control the soil losses in degraded lands. 
Along the twentieth century, soil erosion topic was seeing as a key worldwide environmental problem that affects mainly the food security (Brown 1981) and human health (Oliver and Gregory 2015). Soil erosion in agriculture lands was then more investigated and it was found that intense ploughing (Turtola et al. 2007), use of herbicides (Liu et al. 2016), cultivation of steep slopes (Shi et al. 2012), wrong soil managements (Mohammed et al. 2020a; Li et al. 2020) and subsequent soil compaction (Parker 1995; Al-Dousari et al. 2019) and soil degradation (Hill et al. 1995) resulted in high erosion rates.

Accelerated soil erosion rates were found under different crops, for example, in cereals, were found high in many countries (Santisteban et al. 2006; Nunes et al. 2011; LópezVicente et al. 2015). But other crops also showed high soil erosion rates due to the bare soils. For instance, olive groves are characterised by the higher soil losses such as was found by Nekhay et al. (2009), Fernández et al. (2020) or Sastre et al. (2016). Vineyards presented also higher erosion rates (Rodrigo-Comino 2018), mainly due to the intense ploughing and the lack of vegetation cover and the loss of the canopy during the winter (e.g.,López-Vicente and Álvarez 2018; Ben-Salem et al. 2018; Mirás-Avalos et al. 2020). Citrus plantations also contribute to high erosion rates characterised such as was found in China (Liu et al. 2012) and the Mediterranean belt (Cerdà and Jurgensen 2011). In the last three decades, a growth of the soil erosion measurements found that some other crops contribute to high erosion rates (Panagos et al. 2020).

The mechanization of the agriculture system results in higher erosion rates in citrus, vineyards and olive plantations due to the soil compaction, the removal of the terraces and the loss of hedgerows (e.g.,Karamage et al. 2016; Mutegi et al. 2008; Zemke 2016). Orchards and groves use to contribute with high erosion rates such as the research on apricots (Keesstra et al. 2016), almonds (Raya et al. 2006; Rodrigo-Comino et al. 2018b), persimmons (Bayat et al. 2019; Rodrigo-Comino et al. 2020b), or avocado (Atucha et al. 2013) discovered.

The scientific research devoted to soil erosion found that the highest soil erosion rates were found during the plantation due to the soil compaction (Rodrigo-Comino et al. $2017 \mathrm{a}, \mathrm{b})$ and the reduction in soil hydraulic conductivity (Alagna et al. 2019). This resulted in an increase in runoff generation and soil losses for some years due to the lack of vegetation cover (Cerdà et al. 2017; Rodrigo-Comino et al. 2018c). The impact of the plantation works was found also as the key factor by Rodrigo-Comino et al. (2017a, b) due to the impact of the transport of equipment that results in compacted soils, the bare surfaces and the lack of crop cover due to the low biomass of the recently planted vineyards and the increase in runoff connectivity (Cerdà et al. 2017). The overview given here about the conditions of the agriculture land from the soil erosion point of view shows an environmental problem: an acceleration of the soil losses. Figure 1 shows some examples of erosion processes in vineyards. Moreover, during and after the plantation soil erosion is enhanced. We propose in this research the use of a specific cover crop, the Vicia Sativa roth. to reduce the soil losses during the first year after the plantation to control the peak of soil erosion and, subsequently, preventing the degradation processes during the coming future years. To date, the use of this plant is scarce in the scientific literature. For example, (Novara et al. 2011) for 9-year-old vine plantations in Sicily and different comparisons to other cover crops such as Vicia faba, Trifolium subterraneum, Festuca rubra and Lolium perenne. Also, (Cerdà et al. 2018b) used Vicia Sativa L. in a citrus organic farming in the Canyoles river watershed, Eastern Spain. (Sharaiha and Ziadat 2008) at Jordan, University Station used different plant densities $\left(250,300\right.$, and 350 plants $\left./ \mathrm{m}^{-2}\right)$ under different cropping systems with barley (Hordeum vulgare L.) and common vetch (Vicia sativa L.) to assess differences in soil erosion rates. In an Inceptisol soil type, representative of the Santa Catarina highlands in southern Brazil, (Bertol et al. 2005) also tested the Vicia sativa to assess the possible connections between a crop cycle sequence and water erosion, calcium, magnesium and organic carbon losses. All of them confirmed that a clear reduction in soil and water losses can be found; however, there is a lack of information about the use of this cover crop at the early age of plantation.

To test the efficiency of this soil erosion control measure during the first years after plantation, rainfall simulation experiments were applied and soil samples were collected with field surveys during 3 years (2016, 2017 and 2018) during different seasons. We compared a total of 10 plots with Vicia sativa to 10 control tilled ones. This study is designed for a specific vineyard farm in a localized region of Terres dels Alforins, Moixent municipality, Eastern Spain. However, we hypothesize that the results can be designed for other countries at a regional scale. The feasibility of this methodology can be implemented in other regions of the world having different climatic and soil conditions.

\section{Materials and methods}

\subsection{Study area}

Pago Casa Gran is a certified organic farm located in the traditional viticulture region of Terres dels Alforins, Moixent municipality, in Eastern Spain (Fig. 2a-e). Climate is the dry Mediterranean, with a mean annual rainfall of $350 \mathrm{~mm}$ year ${ }^{-1}$ and average annual temperature $13.8^{\circ} \mathrm{C}$ (Rodrigo-Comino et al. 2020a, b, c). The experimental sites were located in a pediment at the footslope of the Serra 
Fig. 1 View of different fields planted with vineyards and land degradation features. a shows the rills and gullies formation during extreme rainfall events. b Displays the view of recently planted vineyard under Tillage conditions, which results in fields that are a huge source of sediments. c Informs about the accumulation and cracking of sediments in the lower part of a field. d Advises of the intermediate area, where transport is the main mechanism in a large vineyard. e view after the rainfall and the following runoff generation and soil displacement and illustrate how some parts of the field loose soil (see a) but others gain sediments, and the sediments can bury the saplings of vines, and farmers need to dig to avoid the death of the plants. The digging is to rescue the young vines buried by the sediments. $\mathbf{f}$ shows a plant sprouting within the crusted and cracked sediments 1 week after the flood took place in June 2018 in the Els Alforins wine production area in Eastern Iberian Peninsula
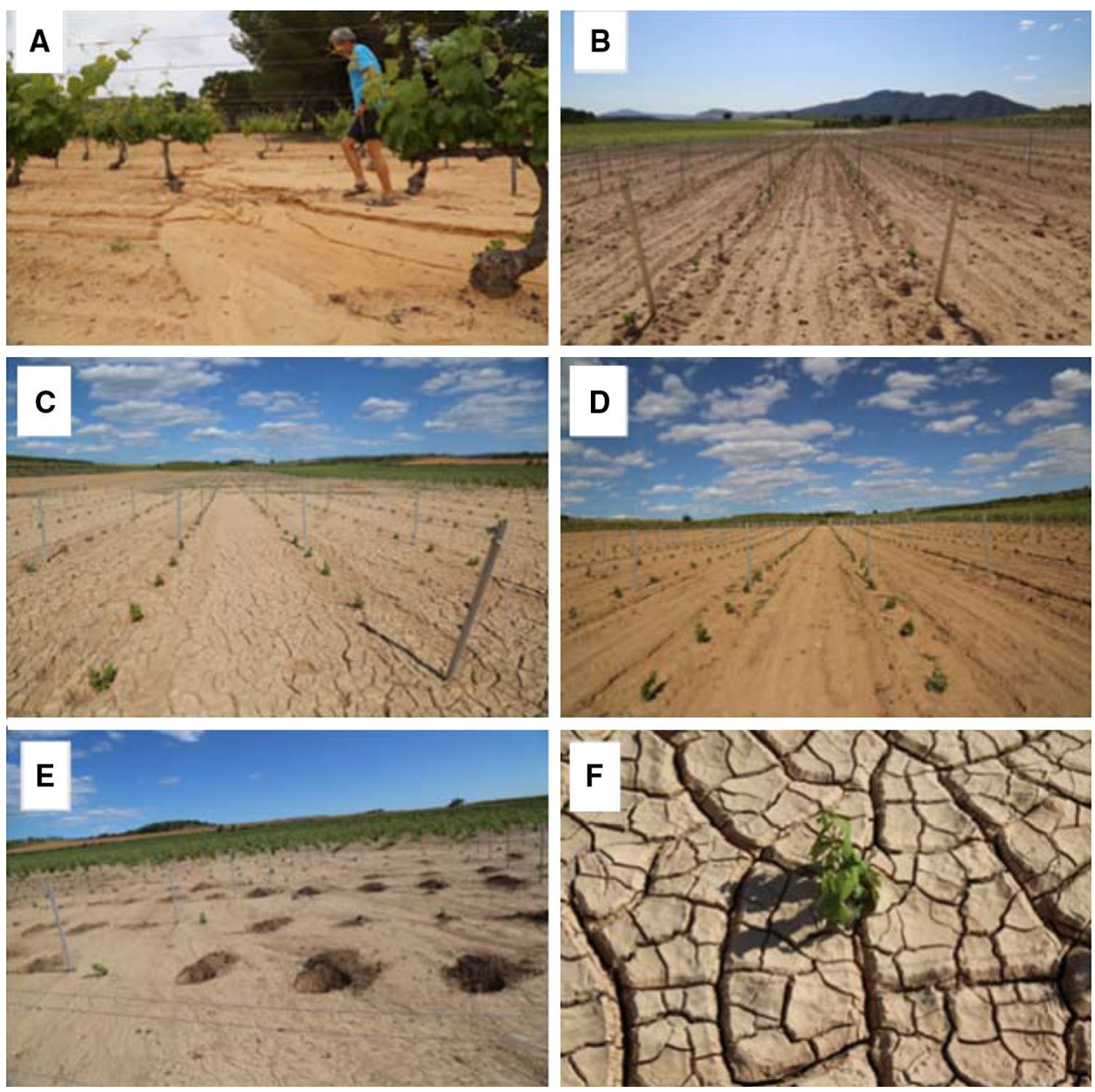

Grossa. The soil is sandy loam Typic Xerofluvent (Soil Survey Staff 2014). The research was carried out during the years 2016, 2017 and 2018. The study area was selected in 2013 when the parcel was an apricot field. In 2014 the apricot trees were removed, the soil deeply ploughed and after 1 year levelled, ploughed again and planted with new vines in January 2016. The rainfall simulation experiments were carried out in February 2016 after the vine plantation, and again during 3 years in August 2016, August 2017 and August 2018. The experiments and sampling collection were carried out in summer, during the traditional Mediterranean drought to avoid spatial and temporal changes in the soil moisture, which highly affect the soil hydrological and erosional (Wei et al. 2007).

We selected two paired study plots within the Casa Pago Gran (Fig. 2e). The Control plot was under Tillage; meanwhile, the Vicia sativa Roth plot was not tilled in the interrow area. The grape (Vitis vinifera $\mathrm{L}$.) variety is Riesling which is the most awarded from the winery and they follow the Valencia Organic Farming Committee (Comité d'Agricultura Ecológica de la Comunitat Valenciana) rules. The Vetch (Vicia sativa Roth) were sown in January at a rate of $60 \mathrm{~kg} \mathrm{ha}^{-1} \mathrm{year}^{-1}$. Hedgerows with olive trees and aromatic plants are present on the farm too to increase the biodiversity. Figure $2 \mathrm{e}$, f shows a view of the study sites, the location of the plots and the layout of the experiment and the sampling strategy. During the plantation works in January 2016 different machinery (tractors, lorries, vans) and the trampling of the workers was present after a levelling of the whole parcel with heavy machinery.

\subsection{Experimental Layout}

Immediately after the wine planting twenty rainfall simulation plots were located at the two research sites: Vicia sativa (10 plots) and Tillage (10 plots). Soil sampling at each plot, and rainfall simulation experiments were performed in January 2019 before the Vicia sativa sown (February) to determine the differences amongst the two experimental sites (Fig. 2e). Later we carried out experiments in August 2016, 2017 and 2018 in the Tillage (Fig. 2g) and the Vicia sativa (Fig. 2h) sites to assess the impact of vegetation cover as a soil erosion control management, and to survey the temporal changes of the soil erosion rates along three experimental 

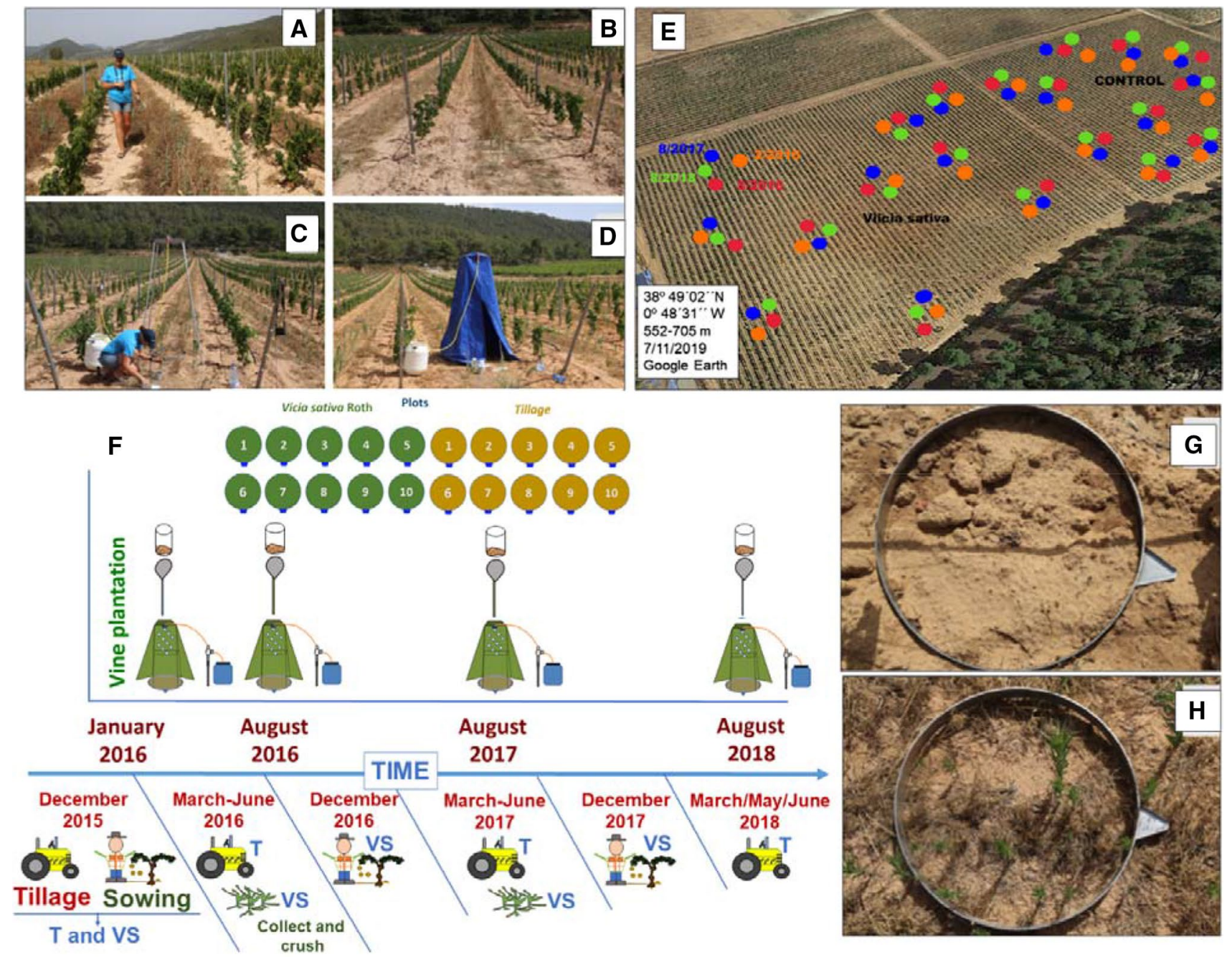

Fig. 2 View of the study sites (a and $\mathbf{b}$ ) and the rainfall simulator (c and d). Location of the study plots and study sites at the Pago Casa Gran research station (e) for Control (Tillage $=\mathrm{T}$ ) and Vicia sativa (VS) plots are shown for the four experimental seasons in February

years. We selected two experimental fields in January 2016 during the plantation of the vines. The plots of the rainfall simulation experiments were located in different parts of the field (Fig. 2e) during each experimental period to construct a temporal series after the plantation. The Tillage plot was tilted four times per year (March, May, July and November). The Vicia sativa plot was treated with a plant chopped machine adapted to a tractor in April, June and August.

\subsection{Rainfall Simulation Experiments, Soil Sampling and Surface Characterisation}

Plant, litter, rock fragment, and bare soil covers were measured before the rainfall simulation experiments and were determined by measuring 100 points regularly distributed at each $0.25 \mathrm{~m}^{2}$ plot, and then, considered as a
2016, August 2016, August 2017 and August 2018. Experimental Layout and timing of the experimental layout (f) and view of two rainfall simulation experimental plots $(\mathbf{g}$ and $\mathbf{h})$

percentage value. Soil sampling took place at each of the 80 research plots (10 in Control and 10 in Vicia sativa plot in February 2016, and August 2016, 2017 and 2018). The samples were taken a $0-6 \mathrm{~cm}$ depth with a ring of $6 \mathrm{~cm}$ of diameter and $6 \mathrm{~cm}$ depth. Grain size, soil moisture and organic matter and bulk density were determined from the samples collected in February 2016. Soil moisture and organic matter and bulk density were measured again at each rainfall simulation plot August in 2016, 2017 and 2018. The pipette method was used to determine the grain size (Deshpande and Telang 1950). Bulk density was measured using the ring method. Soil organic matter was measured using the Walkley-Black method (Walkley and Black 1934). Soil moisture was determined by the desiccation and measured in all the 80 samples. Twenty samples were collected at each sampling period 
(January 2016 and August 2016, 2017 and 2018), 10 for Vicia sativa management and 10 for Tillage.

The experimental setup for the rainfall simulation experiments was identical than for the soil sampling. Ten plots per management (10 Tillage and 10 Vicia sativa) by four seasons (February 2016 and August 2016, 2017 and 2018) were used to carry out a total of 80 rainfall simulation experiments at $55 \mathrm{~mm} \mathrm{~h}^{-1}$ rainfall intensity for one hour on circular paired plots $\left(0.25 \mathrm{~m}^{2}\right)$ (Cerdà et al. 2020). For more detailed information about this rainfall simulator, the readers can visit the previous articles published by Cerdà (1997), Cerdà et al. (1997). For the calibration, more information can be found in the comparisons articles performed under laboratory (Iserloh et al. 2013) and field conditions (Rodrigo-Comino et al. 2016). At each plot, runoff flow was collected at 1-min intervals and water volume was measured. The runoff coefficient was calculated as the percentage of rainfall water leaving the circular plot as overland flow. Runoff samples were desiccated $\left(105^{\circ} \mathrm{C}, 24 \mathrm{~h}\right)$ and sediment yield calculated on a weight basis to calculate soil loss per area and time $\left(\mathrm{Mg} \mathrm{ha}^{-1} \mathrm{~h}^{-1}\right)$. During the rainfall simulation experiments, time to ponding (time required for $40 \%$ of the surface to be ponded; $T_{\mathrm{p}}$, s), time to runoff initiation $\left(T_{\mathrm{r}}, \mathrm{s}\right)$ and time required by runoff to reach the outlet $\left(T_{\mathrm{ro}}\right.$, s) were recorded. $T_{\mathrm{r}}-T_{\mathrm{p}}$ and $T_{\mathrm{ro}}-T_{\mathrm{r}}$ were calculated and they indicate how the ponding is transformed into runoff and how much time the runoff on the soil surface needs to reach the plot outlet. These parameters are good indicators of the hydrological connectivity within the plot.

\subsection{Statistical Analysis}

First, the measured factors with a clear influence on soil erosion were depicted in box plots (Fig. 3) including the median (continuous line), averages (dotted lines) and outliers (black circles): vegetation and rock fragment covers, litter, bulk density, soil water content and organic matter. Then, these above-mentioned variables considered as key factors and the rainfall simulation results $\left(T_{\mathrm{p}}, T_{\mathrm{r}}, T_{\mathrm{ro}}\right.$, soil loss, etc.) were presented in form of tables with averages, standard deviation $( \pm)$, maximum and minimum values (Tables 1, 2 and 3). Furthermore, we compared the results per year and treatment using the $t$ test method. Since all the results showed a non-normal distribution (normality test Shapiro-Wilk), a Tukey test was performed. We considered that significant differences can be relevant at $p<0.001$ levels. Finally, one linear graph (hydrological response per plot and year) and another scatter plot (soil loss vs runoff coefficient) were also depicted (Figs. 4, $5,6,7)$.

\section{Results}

\subsection{Soil properties}

In Fig. 3, soil properties and environmental plot characteristics are presented. During the plantation period early 2016, the soil was almost bare due to the ploughing and the plantation works (Fig. 3a). The most constant cover during this period was the rock fragments with 2.2 and $1.9 \%$ for Tillage and Vicia sativa plots, respectively (Fig. 3b). No statistically significant differences were found (Table 1). In August 2016, the vetch was already established, and the cover was $23.6 \%$ due to the litter $(15.3 \%)$, plants $(6.3 \%)$, rock fragment $(0.5 \%)$. Meanwhile, the Tillage plot was almost bare (1.4\%) with no litter, few plants (0.9\%) some rock fragment (2\%). In August 2017, the Tillage plot was similar, almost bare $(3.4 \%)$ and the Vicia sativa plot reached $41.9 \%$ thanks to the vetch and weed cover (16.4\%), and the litter (25.2\%) (Fig. 3a, c). This cover reached higher values in August 2018 with 54.8\% cover: $27.4 \%$ plants and $25.7 \%$ litter. The litter was a consequence of the dry conditions in August and the pass of the chipped machinery to cut the weeds and the vetch. Statistically significant differences were found along with the three-fieldwork campaign once the vetch cover was established (Table 1).

In February 2016, during the plantation of vines and after 1 year of ploughing and soil preparation for the plantation the soils at the Casa Pago Gran research station shown very low organic matter content (1.05 and $1.04 \%$ ), high bulk density (1.24 and $1.23 \mathrm{~g} \mathrm{~cm}^{-3}$; Fig. $3 \mathrm{~d}$ ), soil moisture (15.2 and $15.1 \%$ ) and Sandy Loam texture (49/31/20\% for Tillage and 49/32/19\% for Vicia sativa), respectively for Tillage and Vicia sativa experimental plots average values. No statistically significant difference between the soil properties mentioned above was found.

In August 2016, after the sowing, germination and colonization of the soil by Vicia sativa, we found changes in some soil properties. For both study sites, Tillage and Vicia sativa, the soil was drying due to the summer drought but the Tillage (5.6\%) was slightly wetter than the Vicia sativa (4.4\%) (Fig. 3e). Organic matter was 1.03 and $1.10 \%$, and soil bulk density 1.17 and $1.25 \mathrm{~g} \mathrm{~cm}^{-3}$ for the Tillage and Vicia sativa plots, respectively. In August 2017 and 2018 , once the vetch was properly established and weeds colonized the plot, some trends can be observed. Soil moisture showed differences reaching 4.3 and $6.0 \%$ in average values for Tillage and Vicia sativa plots (Fig. 3e). It was registered general lower values of soil water content in 2017 and 2018, possibly related to the water consumption by the new plants in the inter-row areas. In August 2017, organic matter was 1.02 and $1.15 \%$, and soil bulk 

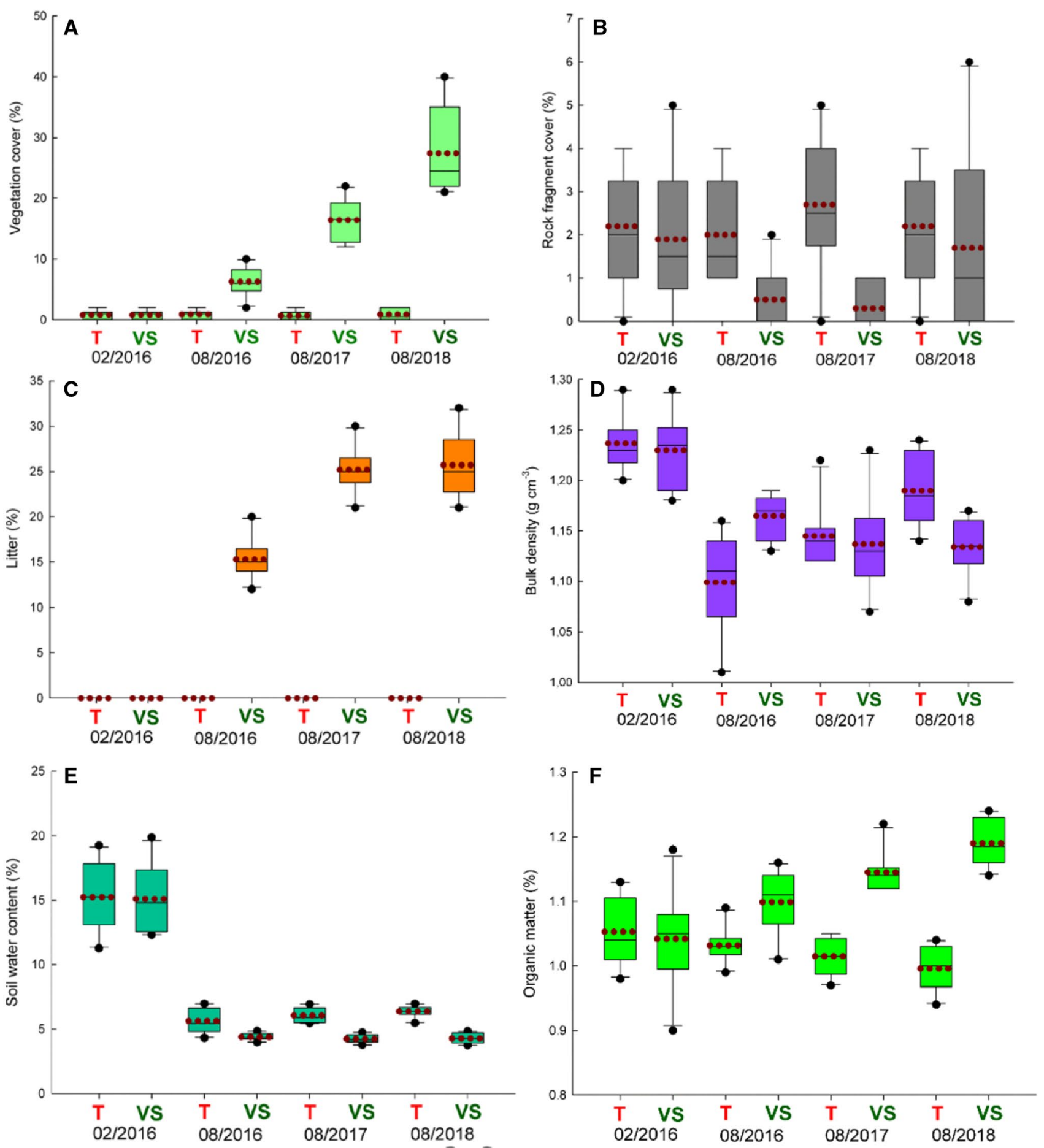

Fig. 3 Pedological and environmental plot characteristics within each management and ring plot sample $(n=10)$. a: vegetation cover $(\%)$; b rock fragment cover (\%); c litter $(\%)$; d bulk density $\left(\mathrm{g} \mathrm{cm}^{-3}\right)$; e

density 1.14 and $1.29 \mathrm{~g} \mathrm{~cm}^{-3}$ for the Tillage and Vicia sativa plots, respectively. Then, in August 2018, the soil moisture showed again a decrease: 4.3 and $6.4 \%$ in average values for Tillage and Vicia sativa plots, respectively. Organic matter was 1.00 and $1.19 \%$ (Fig. 3f), and soil bulk

soil water content (\%); and, f organic matter (\%). Dotted line, mean values; continuous line, median; 5th and 95th are also represented in each box plot extremes; and black circles, outliers

density 1.13 and $1.30 \mathrm{~g} \mathrm{~cm}^{-3}$ for the Tillage and Vicia sativa plots, respectively.

The statistical analysis showed that all plot and pedological characteristics were significantly different between $T$ and VS along August 2016, 2017 and 2018 measurements, 
Table 1 Comparison of plot environmental and pedological characteristics between tillage (T) and Vicia sativa (VS) management

\begin{tabular}{|c|c|c|c|c|c|c|c|c|c|}
\hline Variable & Dates & T vs VS & $\mathrm{T}$ vs $\mathrm{T}$ & VS vs VS & Variable & Dates & T vs VS & $\mathrm{T}$ vs $\mathrm{T}$ & VS vs VS \\
\hline \multirow[t]{5}{*}{$\mathrm{Vc}$} & $02 / 2016$ & $p=1$ & - & - & \multirow[t]{5}{*}{ Litter } & $02 / 2016$ & $p=1$ & - & - \\
\hline & $08 / 2016$ & $p<0.001$ & - & - & & $08 / 2016$ & $p=1$ & - & - \\
\hline & $08 / 2017$ & $p<0.001$ & - & - & & $08 / 2017$ & $p=1$ & - & - \\
\hline & $08 / 2018$ & $p<0.001$ & - & - & & $08 / 2018$ & $p=1$ & - & - \\
\hline & $02 / 2016$ vs $08 / 2018$ & - & $p=0.876$ & $p<0.001$ & & $02 / 2016$ vs $08 / 2018$ & - & $p=1$ & $p<0.001$ \\
\hline \multirow[t]{5}{*}{ Rfc } & $02 / 2016$ & $p=0.660$ & - & - & \multirow[t]{5}{*}{ BD } & $02 / 2016$ & $p=0.630$ & - & - \\
\hline & $08 / 2016$ & $p=0.004$ & - & - & & $08 / 2016$ & $p<0.001$ & - & - \\
\hline & $08 / 2017$ & $p<0.001$ & - & - & & $08 / 2017$ & $p=0.657$ & - & - \\
\hline & $08 / 2018$ & $p=0.547$ & - & - & & $08 / 2018$ & $p<0.001$ & - & - \\
\hline & $02 / 2016$ vs $08 / 2018$ & - & $p=1$ & $p=0.822$ & & $02 / 2016$ vs $08 / 2018$ & - & $p=0.004$ & $p<0.001$ \\
\hline \multirow[t]{5}{*}{ Swc } & $02 / 2016$ & $p=0.908$ & - & - & \multirow[t]{5}{*}{ SOM } & $02 / 2016$ & $p=0.705$ & - & - \\
\hline & $08 / 2016$ & $p<0.001$ & - & - & & $08 / 2016$ & $p=0.002^{*}$ & - & - \\
\hline & $08 / 2017$ & $p<0.001$ & - & - & & $08 / 2017$ & $p<0.001$ & - & - \\
\hline & 08/2018 & $p<0.001$ & - & - & & $08 / 2018$ & $p<0.001$ & - & - \\
\hline & $02 / 2016$ vs $08 / 2018$ & - & $p<0.001$ & $p<0.001$ & & $02 / 2016$ vs $08 / 2018$ & - & $p=0.009$ & $p<0.001$ \\
\hline
\end{tabular}

Significant differences were measured at $p<0.05$

Vc, vegetation cover; Rfc, rock fragment content; Swc, soil water content; BD, bulk densitz; SOM, soil orgnic matter

*Normality and variance tests passed and ANOVA-one way was conducted

Table 2 Comparison of hydrological response between tillage (T) and Vicia sativa (VS) management

\begin{tabular}{|c|c|c|c|c|c|c|c|c|c|c|c|}
\hline \multirow[t]{2}{*}{ Time } & \multirow[t]{2}{*}{$n=10$} & \multicolumn{2}{|l|}{$T_{\mathrm{p}}(\mathrm{s})$} & \multicolumn{2}{|l|}{$T_{\mathrm{r}}(\mathrm{s})$} & \multicolumn{2}{|l|}{$T_{\mathrm{p}}-T_{\mathrm{r}}(\mathrm{s})$} & \multicolumn{2}{|l|}{$T_{\text {ro }}(\mathrm{s})$} & \multicolumn{2}{|l|}{$T_{\mathrm{r}}-T_{\text {ro }}(\mathrm{s})$} \\
\hline & & $\mathrm{T}$ & VS & $\mathrm{T}$ & VS & $\mathrm{T}$ & VS & $\mathrm{T}$ & VS & $\mathrm{T}$ & VS \\
\hline \multirow[t]{5}{*}{$02 / 2016$} & Average & 36.3 & 35.2 & 76.6 & 76.8 & 40.3 & 41.6 & 133.3 & 131.3 & 93.0 & 89.7 \\
\hline & $\mathrm{Sd}$ & 3.4 & 2.3 & 3.6 & 4.6 & 6.5 & 4.5 & 7.8 & 4.5 & 5.3 & 6.4 \\
\hline & Max & 40.0 & 38.0 & 82.0 & 84.0 & 50.0 & 47.0 & 148.0 & 138.0 & 99.0 & 99.0 \\
\hline & Min & 30.0 & 30.0 & 72.0 & 71.0 & 33.0 & 35.0 & 126.0 & 124.0 & 83.0 & 81.0 \\
\hline & Diff & $p=0.408$ & & $p=0.915$ & & $p=0.610$ & & $p=0.498$ & & $p=0.225$ & \\
\hline \multirow[t]{5}{*}{ 08/2016 } & Average & 67.9 & 104.2 & 218.2 & 442.8 & 150.3 & 338.6 & 447.9 & 883.8 & 297.6 & 545.2 \\
\hline & $\mathrm{Sd}$ & 7.3 & 9.9 & 7.9 & 31.7 & 10.7 & 33.1 & 28.1 & 59.1 & 27.6 & 49.0 \\
\hline & Max & 78.0 & 119.0 & 230.0 & 502.0 & 166.0 & 390.0 & 492.0 & 978.0 & 350.0 & 623.0 \\
\hline & Min & 58.0 & 94.0 & 206.0 & 410.0 & 135.0 & 295.0 & 410.0 & 810.0 & 254.0 & 477.0 \\
\hline & Diff & $p<0.001$ & & $p<0.001$ & & $p<0.001$ & & $p<0.001$ & & $p<0.001$ & \\
\hline \multirow[t]{5}{*}{$08 / 2017$} & Average & 65.0 & 141.9 & 209.3 & 530.4 & 144.3 & 388.5 & 427.6 & 1035.4 & 283.3 & 646.9 \\
\hline & $\mathrm{Sd}$ & 3.3 & 24.0 & 13.9 & 25.4 & 14.0 & 19.5 & 19.3 & 86.1 & 25.8 & 99.4 \\
\hline & Max & 69.0 & 178.0 & 232.0 & 585.0 & 170.0 & 420.0 & 465.0 & 1201.0 & 330.0 & 855.0 \\
\hline & Min & 60.0 & 114.0 & 186.0 & 506.0 & 124.0 & 346.0 & 409.0 & 942.0 & 249.0 & 552.0 \\
\hline & Diff & $p<0.001$ & & $p<0.001$ & & $p<0.001$ & & $p<0.001$ & & $p<0.001$ & \\
\hline \multirow[t]{5}{*}{ 08/2018 } & Average & 62.1 & 171.1 & 189.6 & 709.1 & 127.5 & 538.0 & 423.6 & 1368.1 & 296.1 & 830.1 \\
\hline & $\mathrm{Sd}$ & 4.2 & 14.1 & 18.3 & 59.3 & 16.4 & 65.3 & 29.9 & 103.4 & 38.1 & 125.5 \\
\hline & Max & 69.0 & 198.0 & 218.0 & 784.0 & 149.0 & 616.0 & 490.0 & 1547.0 & 385.0 & 1059.0 \\
\hline & Min & 57.0 & 145.0 & 169.0 & 605.0 & 105.0 & 438.0 & 401.0 & 1245.0 & 252.0 & 648.0 \\
\hline & Diff & $p<0.001$ & & $p<0.001$ & & $p<0.001$ & & $p<0.001$ & & $p<0.001$ & \\
\hline
\end{tabular}

Significant differences were measured at $p<0.05$

$T_{\mathrm{p}}$, time to ponding; $T_{\mathrm{r}}$, Time to runoff generation; $T_{\mathrm{ro}}$, time to runoff to outlet; Diff., differences

*Normality and variance tests passed, and ANOVA-one way was conducted. 
Table 3 Comparison between soil erosion results for tillage (T) and Vicia sativa (VS) management types

\begin{tabular}{|c|c|c|c|c|c|c|c|}
\hline \multirow[t]{2}{*}{ Time } & \multirow[t]{2}{*}{$n=10$} & \multicolumn{2}{|l|}{$\mathrm{Rc}(\%)$} & \multicolumn{2}{|l|}{$\mathrm{Sc}\left(\mathrm{g}^{-1}\right)$} & \multicolumn{2}{|c|}{$\operatorname{Er}\left(\mathrm{g} \mathrm{m}^{-2}\right)$} \\
\hline & & $\overline{\mathrm{T}}$ & VS & $\overline{\mathrm{T}}$ & VS & $\overline{\mathrm{T}}$ & VS \\
\hline \multirow[t]{5}{*}{$02 / 2016$} & Average & 45.0 & 45.3 & 22.3 & 23.7 & 550.5 & 589.8 \\
\hline & $\mathrm{Sd}$ & 3.0 & 3.1 & 1.4 & 2.5 & 47.7 & 77.9 \\
\hline & Max & 49.7 & 49.7 & 24.0 & 26.7 & 643.5 & 708.0 \\
\hline & Min & 41.3 & 41.0 & 19.3 & 19.9 & 488.6 & 472.4 \\
\hline & Diff & $p=0.836$ & & $p=0.138$ & & $p=0.19$ & \\
\hline \multirow[t]{5}{*}{$08 / 2016$} & Average & 31.7 & 22.8 & 18.7 & 8.9 & 326.5 & 112.7 \\
\hline & $\mathrm{Sd}$ & 2.5 & 2.0 & 1.5 & 1.1 & 29.3 & 20.5 \\
\hline & Max & 36.0 & 25.6 & 21.1 & 10.3 & 398.4 & 132.3 \\
\hline & Min & 29.1 & 20.1 & 16.9 & 7.3 & 283.4 & 80.1 \\
\hline & Diff & $p<0.001$ & & $p<0.001$ & & $p<0.00$ & \\
\hline \multirow[t]{5}{*}{ 08/2017 } & Average & 32.5 & 16.9 & 18.4 & 5.3 & 328.3 & 49.3 \\
\hline & $\mathrm{Sd}$ & 3.5 & 2.0 & 1.6 & 0.7 & 38.7 & 6.6 \\
\hline & Max & 38.0 & 20.7 & 21.0 & 7.0 & 395.0 & 60.6 \\
\hline & Min & 26.4 & 14.4 & 16.5 & 4.3 & 255.8 & 40.4 \\
\hline & Diff & $p<0.001$ & & $p<0.001$ & & $p<0.00$ & \\
\hline \multirow[t]{5}{*}{$08 / 2018$} & Average & 32.9 & 13.7 & 18.5 & 3.8 & 328.3 & 49.3 \\
\hline & $\mathrm{Sd}$ & 2.4 & 1.9 & 2.3 & 0.5 & 38.7 & 6.6 \\
\hline & Max & 36.3 & 17.0 & 22.0 & 5.0 & 395.0 & 60.6 \\
\hline & Min & 28.7 & 11.1 & 14.0 & 3.0 & 255.8 & 40.4 \\
\hline & Diff & $p<0.001$ & & $p<0.001$ & & $p<0.00$ & \\
\hline
\end{tabular}

Significant differences were measured at $p<0.05$

Rc, runoff coefficient; Sc, sediment concentration; Er, soil erosion; Sd, standard deviation; Diff., differences

*Normality and variance tests passed and ANOVA-one way was conducted
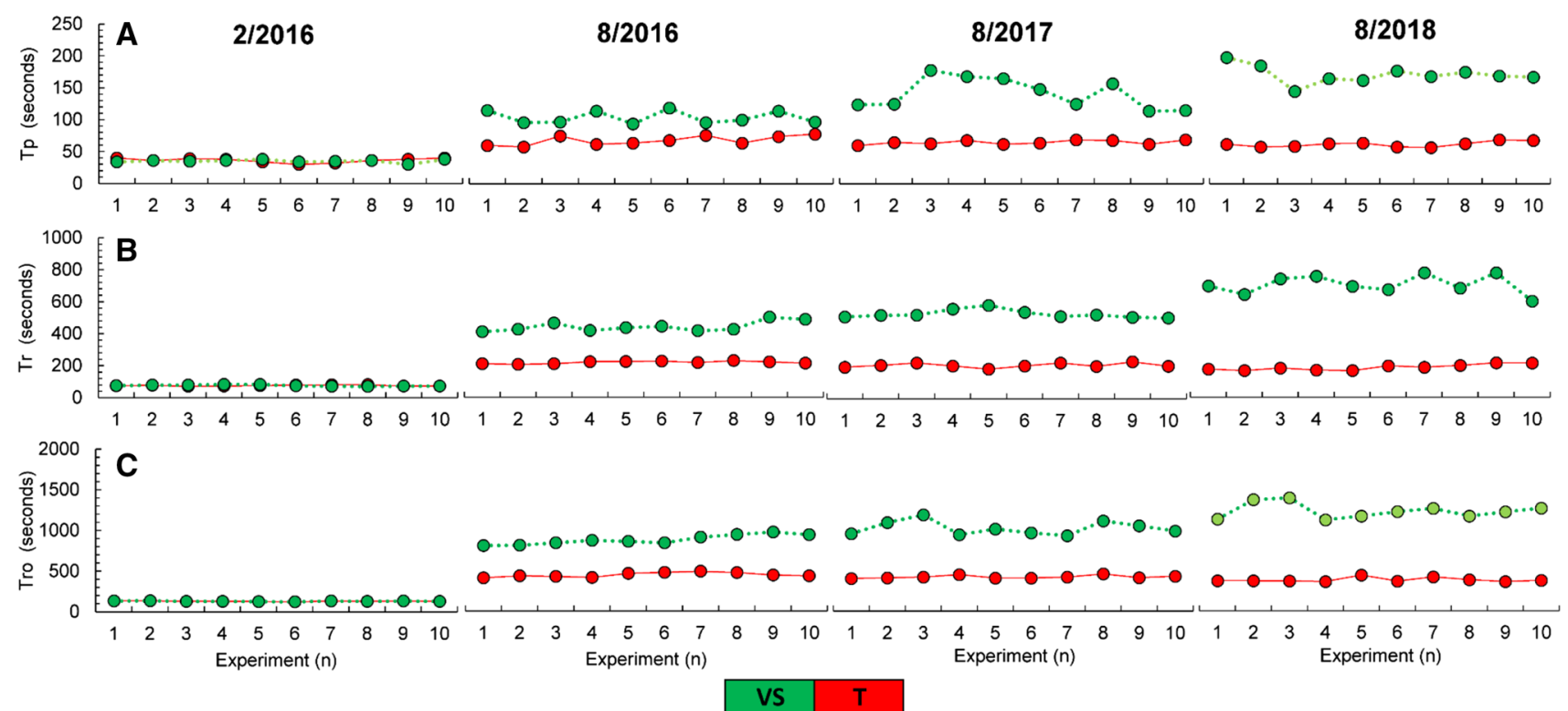

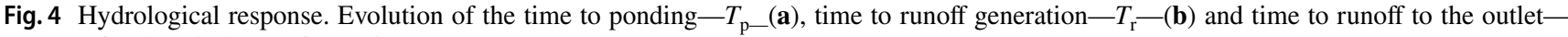
$T_{\mathrm{ro}}-(\mathbf{c})$ for the whole set of experiments 


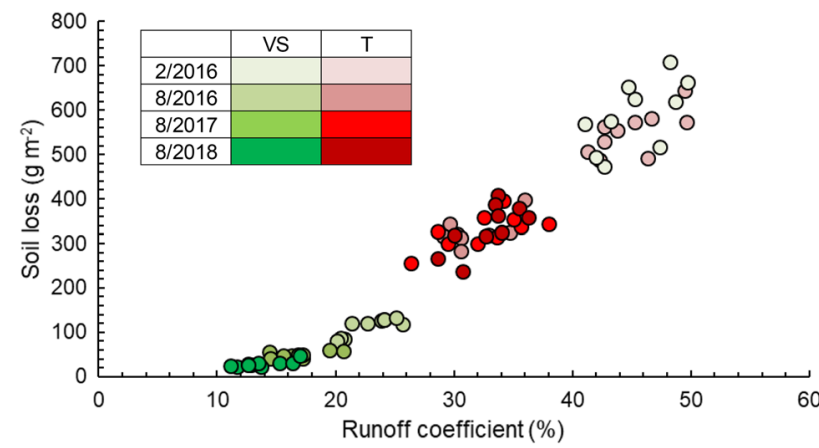

Fig. 5 Relationship between runoff coefficient and soil erosion for the 4 experimental periods in Pago Casa Gran. VS, Vicia sativa plot; T, Tillage plot
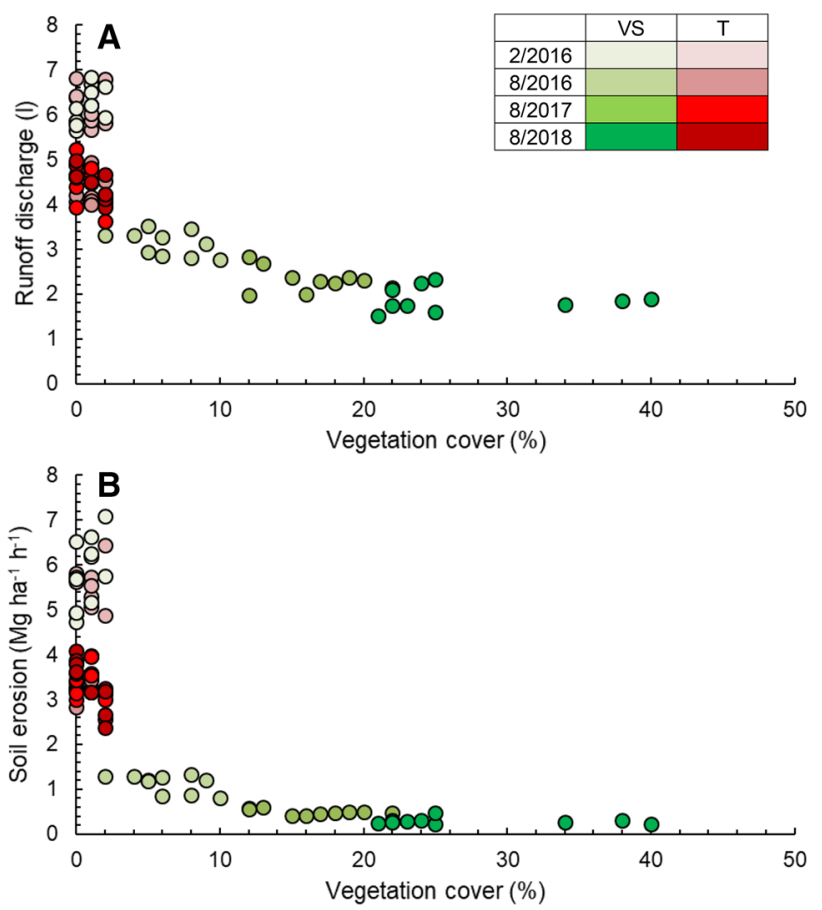

Fig. 6 Relation between the vegetation cover and runoff coefficient (a), and soil erosion (b) for the 4 experimental periods in Pago Casa Gran. VS, Vicia sativa plot; T, tillage plot

but not during January 2016, coinciding with the initial survey before the vetch sown. Once the vetch was established, there was a slight increase in organic matter, which show the same trend in plant and litter cover. On the other hand, it was detected a reduction in soil water content and bulk density. Rock fragments remained similar along the 43 months of research confirming that both soils were similar in January 2016 and the catch crop cover slightly changed some properties.
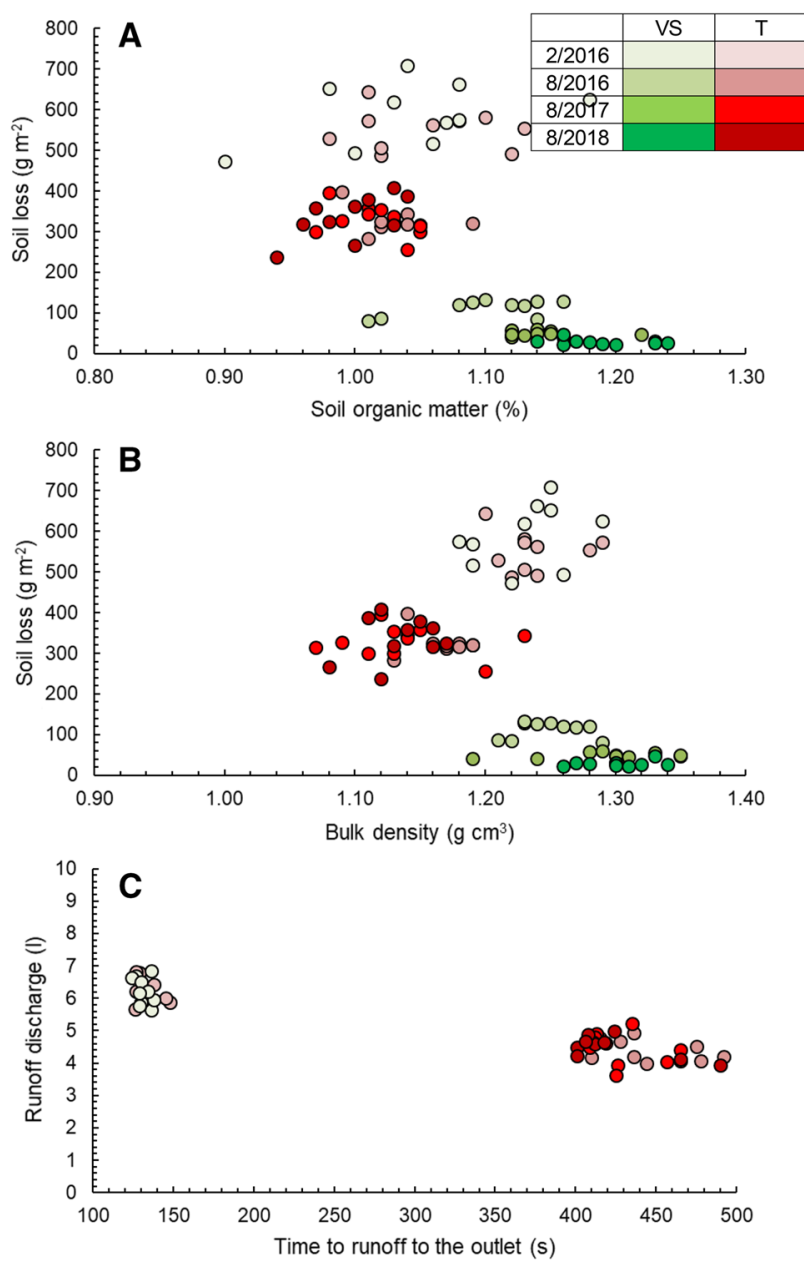

Fig. 7 Relation between the soil organic matter and soil loss (a), bulk density and soil loss (b) and runoff discharge and time to runoff to the outlet (c) for the 4 experimental periods in Pago Casa Gran. VS, Vicia sativa plot; $\mathrm{T}$, tillage plo

\subsection{Runoff Initiation}

During the rainfall simulation experiments, measurements of time to ponding $\left(T_{\mathrm{p}}\right)$, time to runoff $\left(T_{\mathrm{r}}\right)$, and time to runoff outlet $\left(T_{\text {ro }}\right)$, were determined in each plot (Fig. 4). Those parameters show when the soil was ponded when the runoff was initiated and when did reach the plot runoff collector, and they and the $T_{\mathrm{r}}-T_{\mathrm{p}}$ and $T_{\mathrm{ro}}-T_{\mathrm{r}}$ inform about the connectivity of the runoff generation in each plot. Shorter periods inform about high connectivity. $T_{\mathrm{p}}, T_{\mathrm{r}}$ and $T_{\mathrm{ro}}$ were shorter during the plantation works. This was due to bare soil, high soil moisture and trampling of workers. In February 2016 the ponding was reached after $36.3 \mathrm{~s}$ for Tillage and $35.2 \mathrm{~s}$ for Vicia sativa after the rainfall. Runoff was very fast too (76.6 $\mathrm{s}$ and $76.8 \mathrm{~s}$ ) and $T_{\text {ro }}$ after $1333 \mathrm{~s}$ and $131 \mathrm{~s}$. The high soil water content in winter, the soil disturbances due to the plantation works and the lack of vegetation cover resulted in very fast initiation and transfer of surface wash: $T_{\mathrm{r}}-T_{\mathrm{o}}$ 
was 76.6 and $76.8 \mathrm{~s}$ and $T_{\mathrm{ro}}-T_{\mathrm{r}} 93 \mathrm{~s}$ and $89.7 \mathrm{~s}$. In August $2016 T_{\mathrm{r}}-T_{\mathrm{o}}$ was 150.3 and $338.6 \mathrm{~s}$ and $T_{\mathrm{ro}}-T_{\mathrm{r}} 297.6$ and $545 \mathrm{~s}$, respectively, for Tillage and Vicia sativa plots. This delay in the runoff connectivity is due to the drier soil conditions but in the Vicia sativa was due to the delay of ponding (104.2 s), runoff (442.8 s) and runoff outlet (883.8 s) in comparison with the Tillage plot is a consequence of the litter and land cover. The delay in the ponding and runoff generation increased in the August 2017 and August 2018 sampling period in the Vicia sativa plot but there were no changes in the Tillage one. The $T_{\mathrm{p}}$ was 65 and $141.9 \mathrm{~s}$, the $T_{\mathrm{r}} 209.3$ and $283.3 \mathrm{~s}$ and $T_{\mathrm{ro}} 427.6$ and $646.9 \mathrm{~s}$ for the Tillage and Vicia sativa plots in August 2017. One year later the data increased the differences between Tillage and Vicia sativa. The $T_{\mathrm{p}}$ was 62.1 and $171.1 \mathrm{~s}$, the $T_{\mathrm{r}} 189.6$ and $709.1 \mathrm{~s}$ and $T_{\text {ro }}$ 296.10 and $830.10 \mathrm{~s}$ for the Tillage and Vicia sativa plots in August 2018, respectively. In Table 2, we demonstrated that after the plantation (02/2016), there are no statistically significant differences among the hydrological response. After some months $(08 / 2016)$, there are drastically significant differences among parameters $(p<0.001)$.

\subsection{Soil and Water Losses}

The highest soil erosion rates were measured during the wintertime period and immediately after the vine plantation (Fig. 5). In February 2016 runoff discharge 6.8 and 6.21 out of the 13.81 of rainfall for the two studied plots. The runoff sediment concentration was $21 \mathrm{~g}^{-1}$ for the Tillage plots and $26.8 \mathrm{~g}^{-1}$ in the Vicia sativa plots during the planting works, in average values. This resulted in 4.89 and 4.71 $\mathrm{Mg} \mathrm{ha}^{-1} \mathrm{~h}^{-1}$ of soil losses under the high magnitude low frequency simulated rainfall thunderstorms.

In August 2016, Vicia sativa plot was already covered with the vetch and the runoff discharge was reduced to $22.1 \%$ of the rainfall. The reduction was smaller at the Tillage plot (31.7\%). The sediment concentration in the runoff dropped at the Vicia sativa till $8.9 \mathrm{~g} \mathrm{l}^{-1}$ but was similar (20.2 $\left.\mathrm{g} \mathrm{l}^{-1}\right)$ to the results in February 2016. The soil erosion rate declined till 3.27 and $1.13 \mathrm{Mg} \mathrm{ha}^{-1} \mathrm{~h}^{-1}$ for the Tillage and Vicia sativa plot, respectively. The decline in the soil erosion rates for the Vicia sativa plot was constant in August 2017 and 2018 (0.49 and $0.29 \mathrm{Mg} \mathrm{ha}^{-1} \mathrm{~h}^{-1}$, respectively). This was due to a reduction of the runoff discharge (16.9\% and $13.7 \%$ for 2017 and 2018) and the sediment concentration (5.3 and 3.8 for 2017 and 2018). On the contrary, the Tillage plot showed similar values along with the 2017 and 2018 measurements: 3.28 and $3.26 \mathrm{Mg} \mathrm{ha}^{-1} \mathrm{~h}^{-1}$ for the soil erosion rates, 32.5 and $32.9 \%$ for the runoff coefficient, and 18.4 and $18.5 \mathrm{~g} \mathrm{l}^{-1}$ for the runoff sediment concentration in average values.

Finally, in Table 3, we can observe the same trend than in Table 2, where the rainfall simulation results immediately after the plantation does not show statistically significant differences. After the second field campaign, the results are drastically different.

\section{Discussion}

\subsection{The Pago Casa Gran Findings Under the Light of the Current Scientific Knowledge}

The new plantations of vineyards resulted in quick changes in the soil system due to the use and abuse of heavy machinery, the trampling and the removal of most of the vegetation cover (see Fig. 6). This results in high erosion rates such as was determined using rainfall simulation experiments (Rodrigo-Comino et al. 2018a; Negash et al. 2020) and long-term topographical assessments (Rodrigo-Comino and Cerdà 2018). To achieve the sustainability of the agriculture land it is necessary to apply proper management that will reduce soil and water losses and control the impact of the vine plantations. Tillage can contribute to continuous damage to the soil and could promote high water and soil losses (Arnaez et al. 2007; Lieskovský and Kenderessy 2014). In our experimental site at the Pago Casa Gran in Moixent, the tillage maintains high soil erosion rates along the 3 years of monitoring period which confirms previous researches that inform about the damage caused on soil quality, and how to induce high erosion rates. Riezebos and Loerts (1998) found in Paraguay and Chile that mechanically tilled soils shown a rapid decline in organic matter; meanwhile, notillage induced recovery of the organic matter from 1.45 to $1.90 \%$ after 10 years. Mikha and Rice (2004) found that the Kennebec silt loam under continuous Zea mays L. cultivation is very sensitive to tillage as aggregation and $\mathrm{C}$ and $\mathrm{N}$ are drastically reduced.

The increase in organic matter induced by the no-tillage could be responsible for an increase in the quality of the soil structure such as Pagliai et al. (2004) showed. This confirms the damage which tillage induces in the soil system such as Rasmussen (1999) found in his review in Scandinavia. The negative impact of tillage on soil biology, structure and chemical properties is not a new finding (Doran 1980) that is being revisited due to the lack of proper information (Blanco-Canqui and Ruis 2018; Biberdzic et al. 2020; Cerdà et al. 2020) and the lack of long-term monitoring (Hungria et al. 2009; Cerdà et al. 2018b; Piazza et al. 2020; Klik and Rosner 2020).

It is already accepted that tillage can induce soil degradation and high soil erosion rates (Chalise et al. 2020; Dickey et al. 1985) due to the lowering of the soil organic matter, disruption of the soil structure and soil sealing. The scientific community has now the challenge to find solutions to achieve sustainable management that will reduce the soil 
and water losses and preserve soil fertility. There is a need to achieve sustainable management that will allow agriculture to produce healthy food without damaging the soil and water systems (Salvati and Carlucci 2010; Siraw et al. 2020). The strategies to reduce the soil losses and preserve the soil properties request innovative ideas such as the use of mulches. Mulches cover the soil and avoid the raindrop impact and, then, reduce the soil losses (Niziolomski et al. 2020) and improve the soil quality (Alewoye Getie et al. 2020). Mulches also induce a lower emission of greenhouse gas emission (Bamber et al. 2020), and it is mainly applied in the transition from conventional to organic farming (Massaccesi et al. 2020). However, the use of mulching requests a high investment by the farmers as straw, plastic, chopped branches and other materials should be transported and applied in the field (Rodrigo-Comino et al. 2020a). All these reduce the sustainability of the use of mulches.

The use of other strategies such as polymers (Yakupoglu et al. 2019), terracing (Ramos and Porta 1997), mulches (Smets et al. 2008), or contour-ridge tillage (Traore and Birhanu 2019) to reduce the soil losses and improve the soil quality usually results in an extra cost for the farmers. The new agriculture managements to achieve sustainability should reduce the soil erosion rates and should reach the acceptance of the farmers (Marques et al. 2015; Cerdà et al. 2018a). Moreover, the new management should contribute to restoring the soils, which means that the soils will produce the ecosystem services requested by the humankind as the soil is a key component of the Earth System at different scales (Rodrigo-Comino et al. 2018d; Negash et al. 2020). The use of catch crops induces the recovery of the vegetation cover in the agriculture fields. This is very relevant in crops, where the soil surface remains bare due to the continuous and persistent ploughing. And more in vineyards as the vines are deciduous plants and along with the winter the soil is bare. The vegetation cover is definitive as a soil conservation strategy and catch crops contribute to cover and protect the soil surface, avoid the raindrop impact and the surface wash and increase infiltration of rainfall and runoff, and this has been shown in different study sites such as the review done by Basche and DeLonge, (2019) found. Our research in Pago Casa Gran in Moixent demonstrate that the use of catch crops results in a reduction of runoff discharge. And this is due to the lowering of the runoff discharged by the use of the Vicia sativa sp. cover (Fig. 7).

On the contrary, Vicia sativa cover induced a continuous reduction in the soil losses due to the litter and plant cover generated along with the spring. The results presented here should encourage farmers to move from Tillage to Catch Crops covers. The cost of $60 €$ per ha plus the sowing task $(65 €)$ contribute to reducing the soil losses. Our measurements under simulated rainfall experiments show that the soil losses were reduced one order of magnitude along the 3 years of research. And that the impact of the vetch growth along the 3 years. Vetch reduced the soil losses in $2.14 \mathrm{Mg} \mathrm{ha}^{-1} \mathrm{~h}^{-1}$ in $2016,2.79 \mathrm{Mg} \mathrm{ha}^{-1} \mathrm{~h}^{-1}$ in 2017 and 3.07 in $\mathrm{Mg} \mathrm{ha}^{-1} \mathrm{~h}^{-1}$ in 2018. The average reduction in soil loss was $2.67 \mathrm{Mg} \mathrm{ha}^{-1} \mathrm{~h}^{-1}$, and this could be $46.82 € \mathrm{Mg}^{-1}$. Other calculations to shed light on the lack of sustainability of the vineyards is the comparison with the production of the vine. Each year the average production for a mature vineyard in the Casa Pago Gran is of $6000 \mathrm{~kg} \mathrm{ha}^{-1}$, which is 8000 bottles ha $\mathrm{h}^{-1} .1 \mathrm{~h}$ of a 5 years return period thunderstorm will transport in average $2670 \mathrm{~kg}$, or 3560 bottles ha $^{-1}$ of soil following previous estimations conducted in other vineyards (Galati et al. 2015; Pappalardo et al. 2019).

The use of cover crops reduced the soil losses in one order of magnitude in the recent plantations also in other countries but during not early stages (Novara et al. 2013; Biddoccu et al. 2017), but which also validate our results. These findings in vineyards are very promising as the soil losses are very high due to the traditional tillage in vineyards and the lack of any cover along with the autumn, winter and early spring (Martínez-Casasnovas et al. 2005; MartínezCasasnovas and Concepcion Ramos 2009). The research developed at the Pago Casa Gran inform about the positive contribution of the use of cover crops in semiarid agriculture systems, where tillage is the traditional management.

\subsection{Contrasted Soil Erosion Processes Under Plant Cover and Bare Tilled Soils}

Soil losses using cover crop are highly dependent on the amount of runoff generated in a plot. The findings of previous researchers show that when the runoff is high the soil losses are high (Hofmann and Ries 1991; Gardner and Gerrard 2003). Those findings were found under natural rainfall at different plot sizes and rainfall simulation experiments in the field (Martínez-Casasnovas and Concepcion Ramos 2009; Novara et al. 2013; Cerdà et al. 2020) or under laboratory conditions (Mamedov and Levy 2019). Figure 5 demonstrates these relationships per year and also in the whole set of data. Soil erosion at Casa Pago Gran research site is lower as lower is the runoff coefficient. The runoff yield ranges from more than $40 \%$ of the rain to values lower than $20 \%$ due to the use of vetch and the reduction in runoff induces a reduction in soil losses the move from $600 \mathrm{~g} \mathrm{~m}^{-2}$ till values below $100 \mathrm{~g} \mathrm{~m}^{-2}$.

Vegetation is the key control factor to reduce runoff and soil losses. This is demonstrated at Casa Pago Gran with the relationship between plant cover and the runoff discharge and soil losses per plot. Year after year, from 2016 till 2018 the runoff discharge was lower when the vegetation cover increased with the use of vetch yearly. The runoff was reduced from 45 to $14 \%$. The plant cover also protects from the raindrop impact and then the sediment 
delivery was also reduced from 5.9 to 0.29 , which is a drastic change that demonstrates the positive effect of vegetation as soil protection. Figure 6 shows this shift after the use of vetch to control the soil and water losses. Other authors found similar findings when using plant cover to protect the soil and water resources (Mohammad and Adam 2010; Zhu et al. 2015). Vetch was very successful in agriculture lands such as Choi and Daimon (2008) found as green manure to recover $\mathrm{N}$ in the sorghum crops. Ren et al. (2019), Barbosa et al. (2009) and Choi et al. (2016) also found a positive effect of vetch to increase the use of water efficiency and to control the soil losses in agriculture land. This fully agrees with our study, which considered that is a good option for farmers that wish to achieve sustainable agriculture as to reduce the soil losses as the key target.

The use of simulated rainfall experiments allows to control and maintain the rainfall characteristics for different experiments. In our experimental approach, we found that other factors such as vegetation are relevant but the changes in vegetation cover and land management with a cover of vetch results also in changes in the soil properties. Organic matter showed a clear impact on soil erosion as soil with high erosion rates uses to have lower soil organic matter (Berhe and Kleber 2013; Marques et al. 2020). Our finding in agriculture land confirms the previous research such as the one by Reganold et al. (1987) on soil erosion plots and the one by Guerra (1994) on soil organic matter and soil erosion under rainfall simulation experiments. Figure 7 a shows this clear effect of the recovery of vegetation cover and the reduction in the soil losses.

The use of vetch avoids the use of tillage but increases soil bulk density. The effect of no-tillage has been previously researched by Logsdon and Karlen (2004) and Osunbitan et al. (2005) and both show an increase in the soil bulk density values. This is also found in our research (Fig. 7b). Another parameter researched at the Pago Casa Gran vineyards is the time to runoff outlet, which show that the vetch delays the runoff generation and then the soil losses are lower (Fig. 7c). A key discussion issue here is the fact that although the soil bulk density increase with the use of vetch as cover, the runoff decrease. This can be due to the development of macropores (cracks, bioturbation by insects and plant roots) that induce a faster and deeper infiltration of the water (Yi et al. 2019).

This shows the vetch as a nature-based solution to reduce the soil losses and contributes to accomplishing with the Sustainable Development Goals of the United Nations as the vetch is reducing the soil losses and contributing to the infiltration of the runoff and rain (Keesstra et al. 2018; Visser et al. 2019).

\section{Conclusions}

The plantation of new vineyards results in soils affected by high soil and water losses. Tillage and Vicia sativa cover, as catch crops, were applied at Casa Pago Gran for 3 years. Tillage did not induce any relevant change in the soil properties, runoff initiation and water and soil losses. However, the cover of Vicia sativa increases plant and litter cover, and slightly organic matter and bulk density. On the contrary, a decrease in soil water content showed a more elevated water competence among cover crops and vines. Vicia sativa showed a positive effect to reduce the soil and water losses in recently planted vineyards along the first 3 years after plantation; meanwhile, tillage did not show any significant improvement. The results of the research developed in the vineyards of Pago Casa Gran contributes with key information about the use of vetch to reduce the high soil erosion rates found in recently planted vineyards. This study was designed for a specific vineyard but the results can be used to design in other vineyards characterized by bare surfaces, conventional soil management and Mediterranean conditions, which are the majority nowadays. The feasibility of this methodology can be implemented even having different climatic and soil conditions, where Vicia sativa can be planted.

Acknowledgements We thank Nathalie Elisseou Léglise for her kind management of our financial support. We wish to thank the Department of Geography secretariat team (Nieves Gómez, Nieves Dominguez and Susana Tomás) for their support along three decades to our research at the Soil Erosion and Degradation Research team (SEDER), with special thanks to the scientific researchers that as visitors from other research teams contributed to the SEDER research. And we also thank the Laboratory for Geomorphology technicians (León Navarro) for the key contribution to our research. The collaboration of the Geography and Environmental Sciences students was fruitful and enjoyable. The music of Hilari Alonso (Dona'm la mà) was an inspiration during the writing of this paper. This research was funded by the European Union Seventh Framework Programme (FP7/2007-2013) under grant agreement $\mathrm{n}^{\circ} 603498$ (RECARE project). A.C. thanks the Co-operative Research programme from the OECD (Biological Resource Management for Sustainable Agricultural Systems) for its support with the 2016 CRP fellowship (OCDE TAD/CRP JA00088807). We thanks Carlos Laso and Pago Casa Gran for his collaboration in the field and the University of Valencia students for the support in the field.

Funding Open Access funding enabled and organized by Projekt DEAL.

\section{Compliance with ethical standards}

Conflict of interest On behalf of all authors, the corresponding author states that there is no conflict of interest.

Open Access This article is licensed under a Creative Commons Attribution 4.0 International License, which permits use, sharing, adaptation, distribution and reproduction in any medium or format, as long as you give appropriate credit to the original author(s) and the source, 
provide a link to the Creative Commons licence, and indicate if changes were made. The images or other third party material in this article are included in the article's Creative Commons licence, unless indicated otherwise in a credit line to the material. If material is not included in the article's Creative Commons licence and your intended use is not permitted by statutory regulation or exceeds the permitted use, you will need to obtain permission directly from the copyright holder. To view a copy of this licence, visit http://creativecommons.org/licenses/by/4.0/.

\section{References}

Alagna V, Bagarello V, Prima SD et al (2019) Using Beerkan experiments to estimate hydraulic conductivity of a crusted loamy soil in a Mediterranean vineyard. J Hydrol Hydromech 67:191200. https://doi.org/10.2478/johh-2018-0023

Al-Dousari AM, Alsaleh A, Ahmed M et al (2019) Off-road vehicle tracks and grazing points in relation to soil compaction and land degradation. Earth Syst Env 3:471-482. https://doi. org/10.1007/s41748-019-00115-y

Alewoye Getie M, Legesse SA, Mekonnen M, Aschalew A (2020) Soil properties and crop productivity strategies as a potential climate variability adaptation options in Adefwuha Watershed, Ethiopia. Earth Syst Env 4:359-368. https://doi.org/10.1007/ s41748-020-00156-8

Arnaez J, Lasanta T, Ruiz-Flaño P, Ortigosa L (2007) Factors affecting runoff and erosion under simulated rainfall in Mediterranean vineyards. Soil Tillage Res 93:324-334

Atucha A, Merwin IA, Brown MG et al (2013) Soil erosion, runoff and nutrient losses in an avocado (Persea americana Mill) hillside orchard under different groundcover management systems. Plant Soil 368:393-406

Ayres QC (1937) Soil erosion and its control. Soil Sci 43:391

Bamber N, Jones M, Nelson L et al (2020) Life cycle assessment of mulch use on Okanagan apple orchards: part 1-attributional. J Clean Prod 267:121960. https://doi.org/10.1016/j.jclep ro. 2020.121960

Barbosa FT, Bertol I, Luciano RV, Gonzalez AP (2009) Phosphorus losses in water and sediments in runoff of the water erosion in oat and vetch crops seed in contour and downhill. Soil Tillage Res 106:22-28. https://doi.org/10.1016/j.still.2009.09.004

Basche AD, DeLonge MS (2019) Comparing infiltration rates in soils managed with conventional and alternative farming methods: a meta-analysis. PLoS ONE 14:e0215702. https:// doi.org/10.1371/journal.pone.0215702

Bayat F, Monfared AB, Jahansooz MR et al (2019) Analyzing longterm soil erosion in a ridge-shaped persimmon plantation in eastern Spain by means of ISUM measurements. CATENA 183:104176. https://doi.org/10.1016/j.catena.2019.104176

Bayramin I, Erpul G, Erdoğan HE (2006) Use of CORINE methodology to assess soil erosion risk in the semi-arid area of Beypazarı, Ankara. Turk J Agric Forestry 30:81-100

Ben-Salem N, Álvarez S, López-Vicente M (2018) Soil and water conservation in rainfed vineyards with common sainfoin and spontaneous vegetation under different ground conditions. Water 10:1058. https://doi.org/10.3390/w10081058

Berhe AA, Kleber M (2013) Erosion, deposition, and the persistence of soil organic matter: mechanistic considerations and problems with terminology. Earth Surf Proc Land 38:908-912

Bertol I, Guadagnin JC, González AP et al (2005) Soil tillage, water erosion, and calcium, magnesium and organic carbon losses. Sci Agricola 62:578-584. https://doi.org/10.1590/S0103 $-90162005000600011$
Biberdzic M, Barac S, Lalevic D et al (2020) Influence of soil tillage system on soil compaction and winter wheat yield. Chilean J Agric Res 80:80-89. https://doi.org/10.4067/S0718-58392 020000100080

Biddoccu M, Ferraris S, Pitacco A, Cavallo E (2017) Temporal variability of soil management effects on soil hydrological properties, runoff and erosion at the field scale in a hillslope vineyard, North-West Italy. Soil Tillage Res 165:46-58. https ://doi.org/10.1016/j.still.2016.07.017

Blanco-Canqui H, Ruis SJ (2018) No-tillage and soil physical environment. Geoderma 326:164-200

Brown LR (1981) World population growth, soil erosion, and food security. Science 214:995-1002. https://doi.org/10.1126/scien ce. 7302578

Cerdà A (1997) Soil erosion after land abandonment in a semiarid of Southeastern Spain. Arid Soil Res Rehabil 11:163-176

Cerdà A, Jurgensen MF (2011) Ant mounds as a source of sediment on citrus orchard plantations in eastern Spain. A three-scale rainfall simulation approach. CATENA 85:231-236. https:// doi.org/10.1016/j.catena.2011.01.008

Cerdà A, Ibáñez S, Calvo A (1997) Design and operation of a small and portable rainfall simulator for rugged terrain. Soil Technol 11:163-170. https://doi.org/10.1016/S0933-3630(96)00135-3

Cerdà A, Keesstra SD, Rodrigo-Comino J et al (2017) Runoff initiation, soil detachment and connectivity are enhanced as a consequence of vineyards plantations. J Environ Manage 202:268-275. https://doi.org/10.1016/j.jenvman.2017.07.036

Cerdà A, Rodrigo-Comino J, Giménez-Morera A et al (2018) Policies can help to apply successful strategies to control soil and water losses. The case of chipped pruned branches (CPB) in Mediterranean citrus plantations. Land Use Policy 75:734745. https://doi.org/10.1016/j.landusepol.2017.12.052

Cerdà A, Rodrigo-Comino J, Giménez-Morera A, Keesstra SD (2018) Hydrological and erosional impact and farmer's perception on catch crops and weeds in citrus organic farming in Canyoles river watershed, Eastern Spain. Agr Ecosyst Environ 258:49-58. https://doi.org/10.1016/j.agee.2018.02.015

Cerdà A, Rodrigo-Comino J, Yakupoğlu T et al (2020) Tillage versus no-tillage. Soil properties and hydrology in an organic persimmon farm in Eastern Iberian Peninsula. Water 12:1539. https ://doi.org/10.3390/w12061539

Chalise D, Kumar L, Sharma R, Kristiansen P (2020) Assessing the impacts of tillage and Mulch on soil erosion and corn yield. Agronomy 10:63. https://doi.org/10.3390/agronomy 10010063

Choi B, Daimon H (2008) Effect of hairy vetch incorporated as green manure on growth and $\mathrm{N}$ uptake of sorghum crop. Plant Prod Sci 11:211-216. https://doi.org/10.1626/pps.11.211

Choi J-S, Kim M-T, Ryu J-H et al (2016) Effect of legume cover crops and nitrogen fertilization rates on yield and nitrogen use efficiency of waxy corn (Zea mays L.) in no-tillage system. Korean J Soil Sci Fertil 49:531-540. https://doi.org/10.7745/ KJSSF.2016.49.5.531

Dickey EC, Shelton DP, Jasa PJ, Peterson TR (1985) Soil erosion from tillage systems used in soybean and corn residues. Trans ASAE 28:1124-1130. https://doi.org/10.13031/2013.32399

Doran JW (1980) Soil microbial and biochemical changes associated with reduced tillage. Soil Sci Soc Am J 44:765-771. https:// doi.org/10.2136/sssaj1980.03615995004400040022x

Ellison WD (1945) Some effects of raindrops and surface-flow on soil erosion and infiltration. Eos Trans Am Geophys Union 26:415-429. https://doi.org/10.1029/TR026i003p00415

Fernández T, Pérez-García JL, Gómez-López JM et al (2020) Multitemporal analysis of gully erosion in olive groves by means of digital elevation models obtained with aerial photogrammetric and LiDAR data. ISPRS Int J Geo-Information 9:260. https:// doi.org/10.3390/ijgi9040260 
Galati A, Gristina L, Crescimanno M et al (2015) Towards more efficient incentives for agri-environment measures in degraded and eroded vineyards. Land Degrad Dev 26:557-564. https:// doi.org/10.1002/ldr.2389

García-Ruiz JM, Beguería S, Nadal-Romero E et al (2015) A metaanalysis of soil erosion rates across the world. Geomorphology 239:160-173. https://doi.org/10.1016/j.geomorph.2015.03.008

Gardner RAM, Gerrard AJ (2003) Runoff and soil erosion on cultivated rainfed terraces in the Middle Hills of Nepal. Appl Geogr 23:23-45. https://doi.org/10.1016/S0143-6228(02)00069-3

Guerra A (1994) The effect of organic matter content on soil erosion in simulated rainfall experiments in W. Sussex, UK. Soil Use Manag 10:60-64. https://doi.org/10.1111/j.1475-2743.1994. tb00460.x

Hill J, Mégier J, Mehl W (1995) Land degradation, soil erosion and desertification monitoring in Mediterranean ecosystems. Remote Sens Rev 12:107-130. https://doi.org/10.1080/0275725950 9532278

Hofmann L, Ries RE (1991) Relationship of soil and plant characteristics to erosion and runoff on pasture and range. J Soil Water Conserv 46:143-147

Hungria M, Franchini JC, Brandão-Junior O et al (2009) Soil microbial activity and crop sustainability in a long-term experiment with three soil-tillage and two crop-rotation systems. Appl Soil Ecol 42:288-296. https://doi.org/10.1016/j.apsoil.2009.05.005

Iserloh T, Ries JB, Cerdà A, Echeverría MT et al (2013) Comparative measurements with seven rainfall simulators on uniform bare fallow land. Zeitschr für Geomorph Suppl 57:11-26

Karamage F, Zhang C, Ndayisaba F et al (2016) Extent of cropland and related soil erosion risk in Rwanda. Sustainability 8:609. https:// doi.org/10.3390/su8070609

Keesstra S, Pereira P, Novara A et al (2016) Effects of soil management techniques on soil water erosion in apricot orchards. Sci Total Environ 551-552:357-366. https://doi.org/10.1016/j.scito tenv.2016.01.182

Keesstra S, Mol G, De Leeuw J et al (2018) Soil-related sustainable development goals: four concepts to make land degradation neutrality and restoration work. Land 7:133. https://doi.org/10.3390/ land7040133

Klik A, Rosner J (2020) Long-term experience with conservation tillage practices in Austria: impacts on soil erosion processes. Soil Tillage Res 203:104669. https://doi.org/10.1016/j.still 2020.104669

Li Y, Jiang Z, Yu Y et al (2020) Evaluation of soil erosion and sediment deposition rates by the $137 \mathrm{Cs}$ fingerprinting technique at different hillslope positions on a catchment. Environ Monit Assess 192:717. https://doi.org/10.1007/s10661-020-08680-w

Lieskovský J, Kenderessy P (2014) Modelling the effect of vegetation cover and different tillage practices on soil erosion in vineyards: a case study in Vráble (Slovakia) using WATEM/SEDEM. Land Degrad Dev 25:288-296. https://doi.org/10.1002/ldr.2162

Liu Y, Tao Y, Wan KY et al (2012) Runoff and nutrient losses in citrus orchards on sloping land subjected to different surface mulching practices in the Danjiangkou Reservoir area of China. Agric Water Manag 110:34-40. https://doi.org/10.1016/j.agwat .2012.03.011

Liu H, Blagodatsky S, Giese M et al (2016) Impact of herbicide application on soil erosion and induced carbon loss in a rubber plantation of Southwest China. CATENA 145:180-192. https://doi. org/10.1016/j.catena.2016.06.007

Logsdon SD, Karlen DL (2004) Bulk density as a soil quality indivator during conversion to no-tillage. Soil Tillage Res 2004:143-149

López-Vicente M, Álvarez S (2018) Stability and patterns of topsoil water content in rainfed vineyards, olive groves, and cereal fields under different soil and tillage conditions. Agric Water Manag 201:167-176. https://doi.org/10.1016/j.agwat.2018.02.004
López-Vicente M, Quijano L, Gaspar L et al (2015) Severe soil erosion during a 3-day exceptional rainfall event: combining modelling and field data for a fallow cereal field. Hydrol Process 29:2358 2372. https://doi.org/10.1002/hyp.10370

Lutz JF (1935) The relation of soil erosion to certain inherent soil properties. Soil Sci 40:439-458. https://doi.org/10.1097/00010 694-193512000-00002

Mamedov AI, Levy GJ (2019) Soil erosion-runoff relations on cultivated land: Insights from laboratory studies. Eur J Soil Sci 70:686-696. https://doi.org/10.1111/ejss.12759

Marques MJ, Bienes R, Cuadrado J et al (2015) Analysing perceptions attitudes and responses of winegrowers about sustainable land management in Central Spain. Land Degrad Dev 26:458-467. https://doi.org/10.1002/ldr.2355

Marques M, Ruiz-Colmenero M, Bienes R et al (2020) Effects of a permanent soil cover on water dynamics and wine characteristics in a steep vineyard in the Central Spain. Air Soil Water Res 13:1178622120948069. https://doi.org/10.1177/11786 22120948069

Martínez-Casasnovas JA, Concepcion Ramos M (2009) Soil alteration due to erosion, ploughing and levelling of vineyards in north east Spain. Soil Use Manag 25:183-192

Martínez-Casasnovas JA, Ramos MC, Ribes-Dasi M (2005) On-site effects of concentrated flow erosion in vineyard fields: some economic implications. CATENA 60:129-146. https://doi. org/10.1016/j.catena.2004.11.006

Massaccesi L, Rondoni G, Tosti G et al (2020) Data on soil physicochemical properties and biodiversity from conventional, organic and organic mulch-based cropping systems. Data in Brief 31:105718. https://doi.org/10.1016/j.dib.2020.105718

Mikha MM, Rice CW (2004) Tillage and manure effects on soil and aggregate-associated carbon and nitrogen. Soil Sci Soc Am J 68:809-816. https://doi.org/10.2136/sssaj2004.8090

Mirás-Avalos JM, Ramírez-Cuesta JM, Fandiño M et al (2020) Agronomic Practices for reducing soil erosion in hillside vineyards under Atlantic climatic conditions (Galicia, Spain). Soil Syst 4:19. https://doi.org/10.3390/soilsystems4020019

Mohammad AG, Adam MA (2010) The impact of vegetative cover type on runoff and soil erosion under different land uses. CATENA 81:97-103. https://doi.org/10.1016/j.catena.2010.01.008

Mohammed S, Al-Ebraheem A, Holb IJ et al (2020) Soil management effects on soil water erosion and runoff in Central Syriaa comparative evaluation of general linear model and random forest regression. Water 12:2529. https://doi.org/10.3390/ w12092529

Mohammed S, Alsafadi K, Talukdar S et al (2020) Estimation of soil erosion risk in southern part of Syria by using RUSLE integrating geo informatics approach. Remote Sens Appl Soc Env 20:100375. https://doi.org/10.1016/j.rsase.2020.100375

Mutegi JK, Mugendi DN, Verchot LV, Kungu JB (2008) Combining napier grass with leguminous shrubs in contour hedgerows controls soil erosion without competing with crops. Agroforest Syst 74:37-49. https://doi.org/10.1007/s10457-008-9152-3

Negash E, Getachew T, Birhane E, Gebrewahed H (2020) Ecosystem service value distribution along the agroecological gradient in North-Central Ethiopia. Earth Syst Environ 4:107-116. https:// doi.org/10.1007/s41748-020-00149-7

Nekhay O, Arriaza M, Boerboom L (2009) Evaluation of soil erosion risk using analytic network process and GIS: a case study from Spanish mountain olive plantations. J Environ Manage 90:30913104. https://doi.org/10.1016/j.jenvman.2009.04.022

Niziolomski JC, Simmons RW, Jane Rickson R, Hann MJ (2020) Efficacy of mulch and tillage options to reduce runoff and soil loss from asparagus interrows. CATENA 191:104557. https://doi. org/10.1016/j.catena.2020.104557 
Novara A, Gristina L, Saladino SS et al (2011) Soil erosion assessment on tillage and alternative soil managements in a Sicilian vineyard. Soil Tillage Res 117:140-147. https://doi.org/10.1016/j. still.2011.09.007

Novara A, Gristina L, Guaitoli F et al (2013) Managing soil nitrate with cover crops and buffer strips in Sicilian vineyards. Solid Earth 4:255-262. https://doi.org/10.5194/se-4-255-2013

Nunes AN, de Almeida AC, Coelho COA (2011) Impacts of land use and cover type on runoff and soil erosion in a marginal area of Portugal. Appl Geogr 31:687-699. https://doi.org/10.1016/j. apgeog.2010.12.006

Oliver MA, Gregory PJ (2015) Soil, food security and human health: a review. Eur J Soil Sci 66:257-276. https://doi.org/10.1111/ ejss. 12216

Osunbitan JA, Oyedele DJ, Adekalu KO (2005) Tillage effects on bulk density, hydraulic conductivity and strength of a loamy sand soil in southwestern Nigeria. Soil Tillage Res 82:57-64. https://doi. org/10.1016/j.still.2004.05.007

Pagliai M, Vignozzi N, Pellegrini S (2004) Soil structure and the effect of management practices. Soil Tillage Res 79:131-143. https:// doi.org/10.1016/j.still.2004.07.002

Panagos P, Katsoyiannis A (2019) Soil erosion modelling: the new challenges as the result of policy developments in Europe. Environ Res 172:470-474. https://doi.org/10.1016/j.envre s.2019.02.043

Panagos P, Ballabio C, Poesen J et al (2020) A soil erosion indicator for supporting agricultural, environmental and climate policies in the European Union. Remote Sens 12:1365. https://doi.org/10.3390/ rs12091365

Pappalardo SE, Gislimberti L, Ferrarese F et al (2019) Estimation of potential soil erosion in the Prosecco DOCG area (NE Italy), toward a soil footprint of bottled sparkling wine production in different land-management scenarios. PLoS ONE 14:e0210922. https://doi.org/10.1371/journal.pone.0210922

Parker KC (1995) Effects of complex geomorphic history on soil and vegetation patterns on arid alluvial fans. J Arid Environ 30:1939. https://doi.org/10.1016/S0140-1963(95)80036-0

Piazza G, Pellegrino E, Moscatelli MC, Ercoli L (2020) Long-term conservation tillage and nitrogen fertilization effects on soil aggregate distribution, nutrient stocks and enzymatic activities in bulk soil and occluded microaggregates. Soil Tillage Res 196:104482. https://doi.org/10.1016/j.still.2019.104482

Ramos MC, Porta J (1997) Analysis of design criteria for vineyard terraces in the mediterranean area of North East Spain. Soil Technology 10:155-166. https://doi.org/10.1016/S0933 -3630(96)00006-2

Rasmussen KJ (1999) Impact of ploughless soil tillage on yield and soil quality: a Scandinavian review. Soil Tillage Res 53:3-14. https:// doi.org/10.1016/S0167-1987(99)00072-0

Raya AM, Zuazo VHD, Martínez JRF (2006) Soil erosion and runoff response to plant-cover strips on semiarid slopes (SE Spain). Land Degrad Dev 17:1-11. https://doi.org/10.1002/ldr.674

Reganold JP, Elliot LF, Unger YL (1987) Long-term effects of organic and conventional farming on soil erosion. Nature 330:370-372

Ren J, Zhang L, Duan Y et al (2019) Intercropping potato (Solanum tuberosum L.) with hairy vetch (Vicia villosa) increases water use efficiency in dry conditions. Field Crops Res 240:168-176. https://doi.org/10.1016/j.fcr.2018.12.002

Riezebos HT, Loerts AC (1998) Influence of land use change and tillage practice on soil organic matter in southern Brazil and eastern Paraguay. Soil Tillage Res 49:271-275. https://doi.org/10.1016/ S0167-1987(98)00176-7

Rodrigo-Comino J (2018) Five decades of soil erosion research in "terroir". The State-of-the-Art. Earth-Sci Rev 179:436-447. https:// doi.org/10.1016/j.earscirev.2018.02.014
Rodrigo-Comino J, Cerdà A (2018) Improving stock unearthing method to measure soil erosion rates in vineyards. Ecol Ind 85:509-517. https://doi.org/10.1016/j.ecolind.2017.10.042

Rodrigo-Comino J, Iserloh T, Morvan X et al (2016) Soil erosion processes in European vineyards: a qualitative comparison of rainfall simulation measurements in Germany, Spain and France. Hydrology 3:6. https://doi.org/10.3390/hydrology3010006

Rodrigo-Comino J, Brevik E, Cerdà A (2017) The age of vines as a controlling factor of soil erosion processes in Mediterranean vineyards. Sci Total Environ. https://doi.org/10.1016/j.scito tenv.2017.10.204

Rodrigo-Comino J, Brings C, Casper MC et al (2017) Temporal changes in soil water erosion on sloping vineyards in the Ruwer-Mosel Valley. The impact of age and plantation works in young and old vines. J Hydrol Hydromech 2017:65. https://doi. org/10.1515/johh-2017-0022

Rodrigo-Comino J, Keesstra S, Cerdà A (2018) Soil erosion as an environmental concern in vineyards: the case study of Celler del Roure, Eastern Spain, by means of rainfall simulation experiments. Beverages 4:31. https://doi.org/10.3390/beverages402003 1

Rodrigo-Comino J, Martínez-Hernández C, Iserloh T, Cerdà A (2018) Contrasted impact of land abandonment on soil erosion in Mediterranean agriculture fields. Pedosphere 28:617-631

Rodrigo-Comino J, Novara A, Gyasi-Agyei Y et al (2018) Effects of parent material on soil erosion within Mediterranean new vineyard plantations. Eng Geol 246:255-261. https://doi. org/10.1016/j.enggeo.2018.10.006

Rodrigo-Comino J, Senciales JM, Cerdà A, Brevik EC (2018) The multidisciplinary origin of soil geography: a review. Earth Sci Rev 177:114-123. https://doi.org/10.1016/j.earscirev.2017.11.008

Rodrigo-Comino J, Giménez-Morera A, Panagos P et al (2020) The potential of straw mulch as a nature-based solution for soil erosion in olive plantation treated with glyphosate: a biophysical and socioeconomic assessment. Land Degrad Dev 31:1877-1889. https://doi.org/10.1002/ldr.3305

Rodrigo-Comino J, Ponsoda-Carreres M, Salesa D et al (2020) Soil erosion processes in subtropical plantations (Diospyros kaki) managed under flood irrigation in Eastern Spain. Singap J Trop Geogr 41:120-135. https://doi.org/10.1111/sjtg.12307

Rodrigo-Comino J, Senciales-González JM, Terol E et al (2020) Impacts of weather types on soil erosion rates in vineyards at "Celler del Roure" experimental research in Eastern Spain. Atmosphere 11:551. https://doi.org/10.3390/atmos11060551

Salvati L, Carlucci M (2010) Estimating land degradation risk for agriculture in Italy using an indirect approach. Ecol Econ 69:511-518

Salvati L, Zitti M, Perini L (2016) Fifty years on: long-term patterns of land sensitivity to desertification in Italy. Land Degrad Dev 27:97-107. https://doi.org/10.1002/ldr.2226

Santisteban LMD, Casalí J, López JJ (2006) Assessing soil erosion rates in cultivated areas of Navarre (Spain). Earth Surf Proc Land 31:487-506. https://doi.org/10.1002/esp.1281

Sastre B, Barbero-Sierra C, Bienes R et al (2016) Soil loss in an olive grove in Central Spain under cover crops and tillage treatments, and farmer perceptions. J Soils Sediments. https://doi. org/10.1007/s11368-016-1589-9

Sharaiha RK, Ziadat FM (2008) Alternative cropping systems to control soil erosion in the arid to semi-arid areas of Jordan. Arid Land Res Manag 22:16-28. https://doi.org/10.1080/1532498070 1784266

Shi ZH, Fang NF, Wu FZ et al (2012) Soil erosion processes and sediment sorting associated with transport mechanisms on steep slopes. J Hydrol 454-455:123-130. https://doi.org/10.1016/j. jhydrol.2012.06.004 
Siraw Z, Bewket W, Degefu MA (2020) Effects of community-based watershed development on landscape greenness and vegetation cover in the Northwestern highlands of Ethiopia. Earth Syst Environ 4:245-256. https://doi.org/10.1007/s41748-019-00127-8

Smets T, Poesen J, Knapen A (2008) Spatial scale effects on the effectiveness of organic mulches in reducing soil erosion by water. Earth Sci Rev 89:1-12. https://doi.org/10.1016/j.earsc irev.2008.04.001

Smith JR (1914) Soil erosion and its remedy by terracing and tree planting. Science 39:858-862. https://doi.org/10.1126/scien ce. 39.1015 .858

Stamp LD (1938) Land utilization and soil erosion in Nigeria. Geogr Rev 28:32-45. https://doi.org/10.2307/210564

Traore K, Birhanu BZ (2019) Soil Erosion control and moisture conservation using contour ridge tillage in Bougouni and Koutiala, Southern Mali. J Environ Protect 10:1333-1360. https://doi. org/10.4236/jep.2019.1010079

Turtola E, Alakukku L, Uusitalo R (2007) Surface runoff, subsurface drainflow and soil erosion as affected by tillage in a clayey Finnish soil. Agric Food Sci 16:332-351. https://doi. org/10.2137/145960607784125429
Visser S, Keesstra S, Maas G et al (2019) Soil as a basis to create enabling conditions for transitions towards sustainable land management as a key to achieve the SDGs by 2030 . Sustainability 11:6792. https://doi.org/10.3390/su11236792

Wei L, Zhang B, Wang M (2007) Effects of antecedent soil moisture on runoff and soil erosion in alley cropping systems. Agric Water Manag 94:54-62. https://doi.org/10.1016/j.agwat.2007.08.007

Yakupoglu T, Rodrigo-Comino J, Cerdà A (2019) Potential benefits of polymers in soil erosion control for agronomical plans: a laboratory experiment. Agronomy 9:276. https://doi.org/10.3390/agron omy9060276

Yi J, Yang Y, Liu M et al (2019) Characterising macropores and preferential flow of mountainous forest soils with contrasting human disturbances. Soil Res 57:601-614. https://doi.org/10.1071/ SR18198

Zemke JJ (2016) Runoff and soil erosion assessment on forest roads using a small scale rainfall simulator. Hydrology 3:25. https:// doi.org/10.3390/hydrology 3030025

Zhu H, Fu B, Wang S et al (2015) Reducing soil erosion by improving community functional diversity in semi-arid grasslands. J Appl Ecol 52:1063-1072. https://doi.org/10.1111/1365-2664.12442 